\title{
EMPOWERMENT FOR EDUCATION OF STUDENTS WITH SPECIAL EDUCATION NEEDS
}

\author{
Audronė Dumčienė, Saulius Šukys \\ Lithuanian Sports University, Kaunas, Lithuania
}

\begin{abstract}
Background. Teachers who are in favour of education of students with special needs (SEN) together with their peers (inclusive education) appreciate the role of parents in the education process of students. However, Čiuladienè and Paužienè (2012) indicate that the majority of Lithuanian general education schools are not sufficiently prepared for inclusive education.

Methods. The sample consisted of 170 parents of students with SEN in grades 5-10. The scale of Parental Involvement in School was used to establish parental involvement in children's education process.

Results. The parent involvement levels in children's education process were established using three five-point scales: Parent Involvement with Teacher/School - 1.60 points; Teacher Involvement with Parent -2.22 points; Parent Involvement with Child's Schoolwork - 3.03 points.

More educated parents compared to parents with lower education indicated that communicating with teachers they really felt equal partners $\left(\chi^{2}=20.37, p<.001\right)$.

Parents admit that better collaboration between parents and teachers can more encourage open and honest communication between them (63.5\%). A little less than three-quarters of parents often or very often received information from teachers about their children's learning and behaviour. Parents who claimed to have sufficient knowledge of educating their children sometimes indicated that they needed teachers and other professionals to help them with their children's development problems $\left(\chi^{2}=14.11, p<.001\right)$.

Conclusions. Most parents were involved in the education of pupils with SEN at home but they were little involved in their children's educational process at school and other school activities.
\end{abstract}

Keywords: student, special education needs, parent, teacher.

\section{INTRODUCTION}

A ccording to the data of Lithuanian Department of Statistics, in the academic year of 2012/2013, as many as $9.5 \%$ of students with special education needs (SEN) attended general education schools. A variety of education methods can be applied in schools in Lithuania for pupils with SEN. However, research results obtained by Gudonis, Ališauskas, and Rusteika (2011) show that about $60 \%$ of secondary school teachers claim that all students with special education needs should be educated along with their peers in mainstream schools and the education of students with special education needs together peers is beneficial for both parties. Only about $17 \%$ of teachers believe that the most appropriate way to meet the special educational needs of students is a special school.

Teachers who are in favour of education of students with special needs (SEN) together with their peers (inclusive education) appreciate the role of parents in the education process of students. However, teachers who oppose inclusive education, disregard parental involvement in their children's education (Gudonis et al., 2011).

Accordingly to Prunty, Dupont, and McDaid (2012), special education needs is not a reason to choose a special school for the child. Rix, Hall, Nind, Sheehy, and Wearmouth (2009) found that 
co-operation between parents and teacher is not only sharing knowledge and experiences about children with SEN, but also seeking to ensure the continuity of students' with SEN education.

However, Čiuladienè and Paužienè (2012) indicate that the majority of Lithuanian general schools are not sufficiently prepared for inclusive education.

How and why does parental involvement influence children's outcomes?

According to Hill and Taylor (2004), parental involvement increases parents' knowledge and skills so they are better prepared to help their children in activities related to school, in addition to this, parents and school have the same aim in general. Pomerantz, Moorman, and Litwack (2007) believe that the involvement of parents in school activities encourage the development of their children's cognitive and meta-cognitive skills and is beneficial for children because parents' involvement in education can be an example to children. It can also raise their motivation to actively participate in school activities.

Increasing parental involvement in children's education leads to the growth of social skills and thus behaviour problems decrease (El Nokali, Bachman, \& Votruba-Drzal, 2010). Parents from higher socio-economic classes, who accordingly have a better education, are often involved in school activities (Pomerantz et al., 2007).

Sad and Gürbüztürk (2013) argue that equal partnership of parents in the education process positively effects children's learning outcomes and ensures better future perspectives for children, as well as improves children's mental health and social relationships. Children's school success is guaranteed if the work of the school is supported and extended by parents at home.

Increased parental involvement in a child's learning in school at a younger age can forecast higher student achievement of learning in later years (McDonnall, Cavenaugh, \& Giesen, 2012).

The most common parental involvement in children's education is going through assistance in homework assignments. As Carr (2013) suggests, students with SEN experience more difficulties in performing homework assignments than their peers. Parents can structure the children's learning at home, creating a supportive work environment (Carr, 2013). According to Thurston and Navarrete (2010), most parents help their children with SEN to perform homework assignments.
Askeland and Velsvik (2013) claim that relationships with teachers of those parents whose children receive needed special assistance are better than those of other parents.

In our opinion, the empowerment of students with special education needs for education is creation of the potentially favourable environment at school and at home for education which helps reveal the child's strengths and abilities allowing the student to become a potentially valuable member in the society.

Not much is known about the influence of parental activities on the empowerment for education of students with special education needs, the level and importance of parents' selfinvolvement and their involvement in the education process of general education school.

The goal of this research was to reveal the peculiarities of parental activities for empowering students with special educational needs for the education. The object of research was the parental activity for empowering the students with special education needs for education.

Hypothesis: parents of students with special educational needs are not sufficiently involved in empowering these students for education.

\section{METHODS}

Research participants. The sample consisted of 170 parents of students with SEN in grades 5-10. There were 148 mothers and 22 fathers among them. According to the educational classification, the parents were divided into two groups: without higher education and with higher education (university and non-university education).

The empirical study involved a questionnaire survey method. The scale for Parental Involvement in School (Miller-Johnson, Sullivan \& Siman, 2004) was used to investigate the parental involvement in children's education process. This scale consists of 18 statements and includes three subscales: Parent Involvement with Child's Schoolwork and Parent Involvement with Teacher/School, and Teacher Involvement with Parent. There were five possible answers for each of statement (5-point Likert scale).

Factor analysis was performed to examine the Lithuanian version of the scale's structure. The data was suitable for factor analysis (KMO ratio $=$ $83.7, p<.001)$. The three factors explained $57.72 \%$ of the total variance. These factors and component corresponded to the statements abstracted in the 
original version of the scale. All three subscales' internal consistency Cronbach's alpha indicators were respectively $.89, .78$ and .83 .

Percentage distribution of responses was calculated, the mean differences of statistical significance were checked by $\chi^{2}$ and MannWhitney $U$ tests and the level of significance was set at $p<.05$.

\section{RESULTS}

The parent involvement level in children's education process according to the three fivepoint scales reflects the following data: Parent Involvement with Teacher/School -1.60 points; Teacher Involvement with Parent -2.22 points; Parent Involvement with Child's Schoolwork - 3.03 points.

Parent Involvement with Teacher/School. The parents of children with SEN communicated with teachers and other school professionals usually on the phone $(70.6 \%)$ or directly face to face $(65.9 \%)$. We found that $32.9 \%$ of parents that communicated with teachers really felt equal partners and $43.5 \%$ equal felt so only partly. Only part (8.2\%) of parents did not feel equal partners in the process of communication with teachers.

More $(63.9 \%)$ parents with higher education compared to parents with lower education (24.6 percent) indicated that communicating with teachers they really felt equal partners $\left(\chi^{2}=20.37\right.$, $p<.001)$.

The parents of children with SEN supposed better collaboration between parents and teachers could encourage open and honest communication between them (63.5\%) as well as organized activities for families (31.2\%). However, they preferred the form of pedagogical communication to the individual discussions with teachers (72.9\%).

The research findings revealed that higher educated parents than parents with lower education more often considered open and sincere communication as a means to promote cooperation (respectively $80.6 \%$ and $59.0 \% \cdot \chi^{2}=4.18, p<.05$ ).

We found that there were parents $(12.4 \%)$ who did not know what learning problems their child had. Some parents $(18.8 \%)$ said that their children did not have any learning problems. The remaining part of parents reported that their children had learning difficulties (52.4\%), learning disorders (14.1\%) and learning disabilities (2.4\%). Only $32.4 \%$ of parents reported that their knowledge was sufficient for their children's education, $55.9 \%$ indicated that their knowledge was partially sufficient and $11.8 \%$ pointed out that their knowledge was insufficient.

The results of this research demonstrated that the majority of parents $(70.0 \%)$ would like to have help with their children's learning and health problems (4.1\%).

More than half $(60.6 \%)$ of the parents with children who had special educational needs were involved in their children's education process, $29.4 \%$ of parents were involved sometimes and the rest $(10.0 \%)$ said that they were not involved in their children's education. Parents who claimed to have enough knowledge of how to educate their children, compared to parents having less or lack of knowledge were involved in ongoing school activities (Mann-Whitney $U=1842.0, p<.001$ ).

Teacher Involvement with Parents. A little less than three-quarters of parents of children with special education needs often or very often received information from teachers about their children's learning and behaviour. But one-quarter of respondents reported receiving this information rarely or did not receive it at all.

Analysis of the results revealed that those parents who were felt equal partners with teachers, were more likely to engage in school activities (Mann-Whitney $U=1871.5, p<.01$ ) and more often believed that teachers were involved in the interaction with them (Mann-Whitney $U=1775.0$; $p<.01)$.

Table 1. Levels (score) of parent involvement in education via partnership with teachers

\begin{tabular}{|l|c|c|}
\hline \multirow{2}{*}{$\begin{array}{c}\text { The field of parent } \\
\text { involvement in the } \\
\text { education }\end{array}$} & \multicolumn{2}{|c|}{$\begin{array}{c}\text { Parent groups according to the } \\
\text { level of partnership with teachers }\end{array}$} \\
\cline { 2 - 3 } & Equal partners & $\begin{array}{c}\text { Unequal } \\
\text { partners }\end{array}$ \\
\hline $\begin{array}{l}\text { Parent Involvement with } \\
\text { Child's Schoolwork }\end{array}$ & 3.08 & 2.83 \\
\hline $\begin{array}{l}\text { Parent Involvement with } \\
\text { Teacher/School }\end{array}$ & 1.68 & $1.33^{*}$ \\
\hline $\begin{array}{l}\text { Teacher Involvement } \\
\text { with Parent }\end{array}$ & 2.33 & $1.85 *$ \\
\hline
\end{tabular}

Note. $*-p<.01$. 
Table 2. Levels (score) of parent interest in children's success in school via partnership with teachers

\begin{tabular}{|l|c|c|}
\hline \multirow{2}{*}{\multicolumn{1}{|c|}{ Interest rate }} & \multicolumn{2}{|c|}{$\begin{array}{c}\text { Parent groups according to the } \\
\text { level of partnership }\end{array}$} \\
\cline { 2 - 3 } & $\begin{array}{c}\text { Equal partners } \\
(\%, \boldsymbol{n})\end{array}$ & $\begin{array}{c}\text { Unequal } \\
\text { partners }(\%, \boldsymbol{n})\end{array}$ \\
\hline Never & $3.1(4)$ & $10.0(4)$
\end{tabular}

Those parents who were involved in children's education problems were often interested in children's learning outcomes (Mann-Whitney $U-741.0, p<.01)$. Also these parents compared to parents not interested in the education problems of their children, were likely to engage in school activities more often (Mann-Whitney $U-464.0$, $p<.01)$.

Parents who were involved in dealing with children's education problems much more preferred direct communication with teachers and other school professionals (respectively $68.6 \%$ and $\left.41.2 \%, \chi^{2}=5.13, p<.05\right)$.

Parents who claimed to have sufficient knowledge of educating their children sometimes indicated that they needed teachers' and other professionals' help with child development issues (respectively $50.9 \%$ and $79.1 \%, \chi^{2}=14.11$, $p<.001)$. On the other hand, more of these parents, compared to those having less or no knowledge how to educate their children, said that they were involved in education of their children (respectively $76.4 \%$ and $53.0 \%, \chi^{2}=8.51, p<.01$ ).

Parent Involvement with Child's Schoolwork. Children with special educational needs usually receive help from their mother (51.2\%) and much less from their father $(21.2 \%)$ to do their homework. Higher grade students more often performed their homework independently than with their parents. The majority did their homework independently $\left(\chi^{2}=14.62, p<.01\right)$.

Parents' involvement in their children's education at home was assessed as follows: having enough knowledge of how to educate children with SEN -3.20 points, while having non enough or no knowledge -2.94 points $(p<.001)$.

\section{DISCUSSION}

The study hypothesis was confirmed as the parents evaluated their involvement in the empowerment of education of students with SEN in three areas of its activities on a scale of five possible points, from 3.03 to 1.6 points on average.

The study revealed that only less than one-third parents (32.9\%) actually felt equal partners while communicating with teachers.

Kim et al. (2012 a) found that parents were more likely to become involved in their children's education, when the parents and teachers' relationship was tantamount and parents felt that teachers understood and supported them. Conversely, when the relationship between parents and teachers is not equivalent, decreasing the probability that cooperation will be effective and beneficial for the child (Kim et al., 2012 b). According to the Oostdam and Hooge (2013), rather than engaging in dialogue with parents, teachers more frequently tend to tell parents what to do or keep parents at a "safe distance".

The study found that parents who felt equal partners communicating with teachers often asked about their children's success at school compared to those who did not feel like equal partners $\left(\chi^{2}=\right.$ $13.70, p<.01)$.

Although parental involvement in children's education is often cited as one of the school's priorities for action, it still not acceptable to involve parents as partners in their children's education process (Oostdam \& Hooge, 2013).

Oostdam and Hooge (2013) argue that parents usually take more interest in the child's achievements and try to find the contact with the teacher, but they become disillusioned, dissatisfied with their children's academic achievements. Thus, both the teacher's educational goals and parental involvement in the education process can have a significant impact on children's learning outcomes (El Nokali et al., 2010).

It is very important to note that parents engaged in education can better plan, influence and control the situation at home. This factor is very important in order to create a safe and intellectual environment for the stimulation of the child's development at home (Oostdam \& Hooge, 2013).

Our study shows that more $(63.9 \%)$ of parents with higher education communicating with 
teachers feel equal partners. Hornby and Lafaele (2011), Pomerantz et al. (2007) argue that parental education may be a barrier to involvement in children's education. Lower educated parents lack knowledge when they have to explain the child how to do the homework assignments. Also lower educated parents think that the teachers better than they know how to educate children and are hesitant to interact with teachers as equal partners.

Thus, the school could promote parent-teacher collaboration. Even $63.5 \%$ of our respondents mentioned the open and frank communication between teachers and parents as a means to promote cooperation.

Al-Shammari and Yawkey (2008) indicated that parents engaged in the education of their children obtained useful information from teachers about helpful education methods of students with SEN at home. Cooperation with parents is beneficial for teachers as well because it allows a more comprehensive knowledge of having students with SEN, their families and home environment.

Comparing the answers of parents of differently aged children showed a statistically significant difference $(p<.05)$, indicating less frequent involvement of older children's parents in their children's education. Results from this study confirm the study results McDonnall et al. (2012), which show that the parents of students in higher grades were less involved in school activities.

Our results revealed that almost two-thirds of parents would like to have more knowledge of their child's education. This may indicate a complexity of the curriculum content and the parents need knowledge of how they can help their child at home to carry out homework assignments. This tendency was found by others researchers as well ( $\mathrm{Sad} \&$ Gürbüztürk, 2013; Patall, Cooper, \& Robinson, 2008), pointing to the lack of parent involvement. This study showed that higher educated parents than parents with lower education more often indicated that they would like teachers and other professionals to help them in understanding how they could help their children with SEN at home.

\section{CONCLUSIONS}

The parents of children with SEN are not enough involved in their children's education at home and especially at school, which would empower their children for education.

Most parents are involved in the education of students with SEN at home, but they are little involved in the education process at school and other school activities.

Less than one-third of parents actually feel equal partners when communicating with teachers, but among them only $63.9 \%$ of parents were with higher education.

Parents who communicate with teachers feel equal partners, they will more likely engage in ongoing school activities and teachers more often cooperate with them.

\section{REFERENCES}

Al-Shammari, Z., \& Yawkey, T. D. (2008). Extent of parental involvement in improving the students' levels in special education programs in Kuwait. Journal of Instructional Psychology, 35(2), 140-150.

Askeland, J. A., \& Velsvik, B. I. (2013). Parents of students who struggle in school: Are they satisfied with their children's education and their own involvement? Scandinavian Journal of Disability Research, 15(2), 89-107.

Carr, N. S. (2013). Increasing the effectiveness of homework for all learners in the inclusive classroom. School Community Journal, 23(1), 169-182.

Čiuladienè, G., \& Paužienè, L. (2012) Iššūkiai mokyklai: inkliuzijos link. Retrieved from http://www.smm.lt/ uploads/documents/kiti/Issukiai_mokyklai.pdf

El Nokali, N. E., Bachman, H. J., \& Votruba-Drzal, E. (2010). Parent involvement and children's academic and social development in elementary school. Child Development, 81(3), 988-1005.

Gudonis, V., Ališauskas, A., \& Rusteika, M. (2011). Specialiosios pedagoginès pagalbos teikimas bendrojo lavinimo mokyklose: mokinių ir mokytojų požiūris. Pedagogika, 101, 91-97.

Hill, N. E., \& Taylor, L. C. (2004). Parental school involvement and children's academic achievement: Pragmatics and issues. Current Directions in Psychological Science, 13, 161-164.

Hornby, G., \& Lafaele, R. (2011). Barriers to parental involvement in education: An explanatory model. Educational Review, 63(1), 37-52.

Kim, E. M., Mike, K. M., Sheridan, S. M., Koziol, N., Ryu, J. H., \& Rispoli, K. M. (2012 a). Congruence within the parent-teacher relationship: Associations with children's functioning (CYFS Working Paper 
No. 2012-2). Retrieved from http://cyfs.unl.edu/docs/ working_papers/CYFS_Working_Paper_2012_2. pdfKim, E. M., Sheridan, S. M., Kwon, K., Woods, K. E., Semke, C. A., \& Sjuts, T. M. (2012 b). Conjoint behavioral consultation and parent participation: The role of parent-teacher relationships (CYFS Working Paper No. 2012-1). Retrieved from http://cyfs.unl.edu/docs/working_papers/CYFS Working_Paper_2012_1.pdf

McDonnall, M. C., Cavenaugh, B. S., \& Giesen, J. M. (2012). The Relationship between Parental Involvement and Mathematics Achievement for Students with Visual Impairments. The Journal of Special Education, 45(4) 204-215.

Miller-Johnson, S., Sullivan, T. N., \& Siman, T. S. (2004). Multisite Violence Prevention Project. Evaluating the impact of interventions in the multisite violence prevention study: Samples, procedures, and measures. American Journal of Preventive Medicine, 26(1), 48-61.

Oostdam, R., \& Hooge, E. (2013). Making the difference with active parenting; forming educational partnerships between parents and schools. European Journal of Psychology of Education, 28, 337-351.
Patall, E. A., Cooper, H., \& Robinson, J. C. (2008). Parental involvement in homework: A research synthesis. Review of Educational Research, 78(4), 1039-1101.

Pomerantz, E. M., Moorman, E. A., \& Litwack, S. D. (2007). Article Review: The How, Whom, and Why of parents' involvement in children's academic lives: More is not always better. Review of Educational Research, 77(3), 373-410.

Prunty, A., Dupont, M., \& McDaid, R. (2012) Voices of students with special educational needs (SEN): Views on schooling. Support for Learning, 27(1), 29-36.

Rix, J., Hall, K., Nind, M., Sheehy, K., \& Wearmouth, J. (2009). What pedagogical approaches can effectively include children with special educational needs in mainstream classrooms? A systematic literature review. Support for Learning, 24(2), 86-94.

Şad, S. N., \& Gürbüztürk, O. (2013). Primary school students' parents' level of involvement into their children's education. Educational Sciences: Theory \& Practice, 13(2), 1006-1011.

Thurston, L. P., \& Navarrete, L. A. (2010). Rural, poverty-level mothers: A comparative study of those with and without children who have special needs. Rural Special Education Quarterly. Thirtieth Anniversary, 30(1), 39-46. 